\title{
タイミングベルトプーリーの高機能化事例について
}

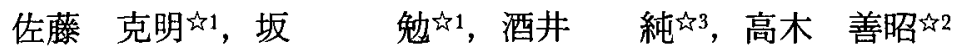

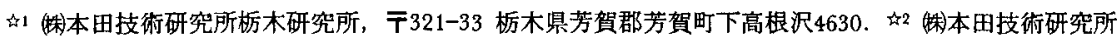 \\ 和光研究所， $\mathbf{7} 351-01$ 和光市中央1-4-1. 好 3 日立粉末治金侏粉末冶金事業部機械部品設計部, \\ 于271 松戸市稔台 520 .
}

\section{Extra High Functions Examples of Timing Belt Pulleys for Automotive Engine}

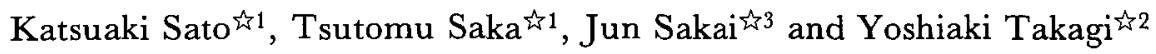 \\ 41 Tochigi R \& D Center, Honda R \& D Co., Ltd., 4630 Shimotakanezawa Haga-machi, Tochigi 321-33. \\ ty2 Wako R \& D Center, Honda R \& D Co., Ltd., 1-4-1 Chuo, Wako 351-01. 诂 Mechanical Parts Design \\ Dept., Powdered Metals Product Div., Hitachi Powdered Metals Co., Ltd., 520 Minoridai, Matsudo 271.
}

Received July 11, 1996

\section{SYNOPSIS}

The pulleys are used to be produced by powder metal due to cost performance and high productivity. Recently, the timing belt pulleys for automotive engine are required extra high functions which have sensor or light weight, and the complex shape pulleys are tend to increase. This report introduces the examples of the design and engineering of these pulleys as follows.

1)The light weight pulleys with thin wall curtain shape rim are lighter than stamping pulleys.

2)The cam shaft pulleys with sensing cam are manufactured as utilizing powder flow during compacting.

3)The crank shaft pulleys with sensing cam at flange portion for miss fire detection have high accuracy of angle phase between key way and sensing cam.

KEY WORDS

Pulley, Light weight, Sensing cam, High accuracy

1 緒 言
クランクプーリーからカムシャフトへの動力伝達 の機能を持つ自動車エンジン用タイミングベルトプ ーリーにはコスト,生産性の理由により焼結材が比較 的多く用いられている。

近年，基本的機能である動力伝達に加えて，低燃費 を目的とした軽量化や制御信号および失火検知用の センシンク機能 (カム) の付加等の高機能化ニーズが 高まりつつある.そこで，本報仕自動車エンジ用夕 イミングベルトプーリーの変選や,プーリーに要求さ れる特性を巡りながら，その高機能化に対する粉末冶 金製法での生産技術的対応を含めた開発事例につい て紹介する。

Fig. 1 はプーリーの使用籄所を示す.

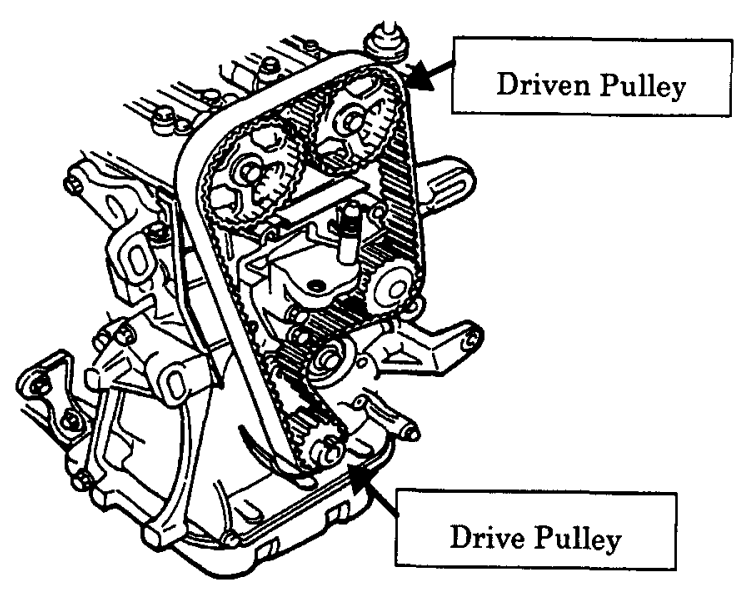

Fig.' 1 Application place. 


\section{2 プーリーの機能的変遷}

2.1 ドリブンプーリーについて

1970 年代のニースは,クランクシャフトからカ ムシャフトへの動力伝達が主であり,製法は鋳物の削 り出しであった. 1970 年代後半からコストダウン ニーズより焼結に置き換えられている。

1980 年代に入ると, コンパクト, 軽量化ニースか らプーリーの小径化が実施され，半ばからは，燃料系 の電子制御化から,センサー機能が要求されてきた.

また,より一層の軽量化を狙い歯襄の肉抜きも実施さ れている.現在は，板金性プーリーを凌ぐ軽量化を図 った物も具現化されている.

Fig. 2 はドリブンプーリーの変遷を示す.

2.2 ドライブプーリーについて

ドライブプーリーは，焼結に適した形状から，19 70 年代からすでに焼結化が実施され，1980年代 に入りコンパクトニースから，小径化が実施された. また，脱着性（フレッデイグ防止）から内径セレーション 形状の採用が見られた.1996 年に入り対米の失火 検知対応からセンサー機能が要求されている.

Fig. 3 はドライブプーリーの変還を示す.

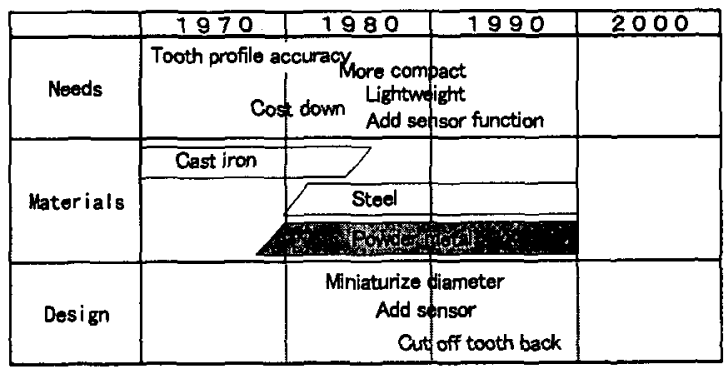

Fig. 2 Driven pulley transition.

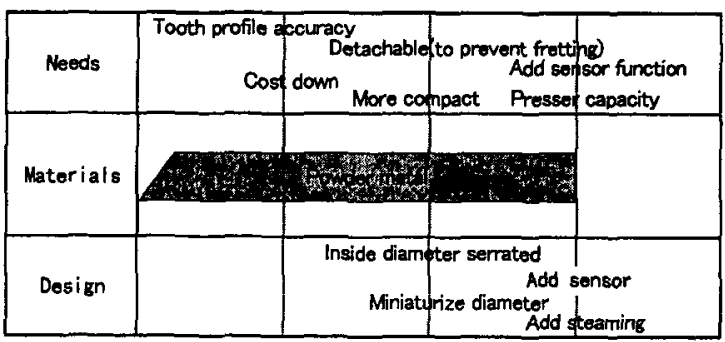

Fig. 3 Drive pulley transition.
3 プーリーに要求される特性と対応

3.1 ドリブンプーリーについて

ドリブンプーリーに要求される特性としては，第一 に当然のことながら動力伝達を行うための強度・精度 がありつきに，慣性モーメントの低減からの軽量化， センサー機能を満たす高機能化,さらに不変のニース であるコストダウンが要求されている.

軽量化については，具体的対応として

(1)圃・リブ部の薄肉化

(2)ブ本数の削減

(3)小徍化

高機能化については，具体的対応として

(1)各種センサーの付加（一体成形）

(2)キーの一体化

コストダウンについては，褚雑形状化する製品をい かに，切削加エレスで製造出来るかに塗かっており 設計段階から最適形状の検討を行っている。

これらの要求を具現化する生産技術対応として

(1)最適な形状設計

(2)金型棈造・機構の改良を行っている.

Fig. 4 はドリブンプーリーのニーズと対応手法の

関連を示す。

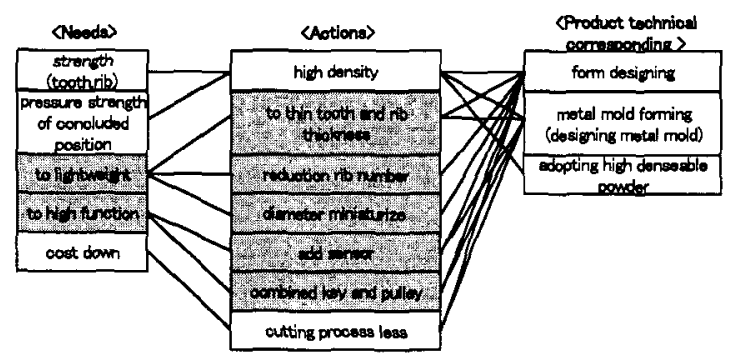

Fig. 4 Needs of driven pulley and method of production technical design.

3.2 ドライププーリーについて

ドライププーリーに要求される特性としては,クラ ンクシャフト締結部の面圧強度と脱着性, センサー機 能を満たす高機能化が要求されている.

面圧強度については，具体的対応として

(1)スチーム処理

高機能化については，具体的対応として

(1)各種センサーの付加（一体成形）

(2) キーの一体化

(3)ベルトガイドの一体化を行っている. 
脱着性については，具体的対応として

(1)フレッテング防止から, 内径のセレーション化 これらの要求を具現化する為の生産技術対応 として

ドリブンプーリー同様に，

(1)最適な形状設計

(2)金型構造・機構の改良を行っている.

Fig. 5 はドライブプーリーのニースと対応手法の

関連を示す.

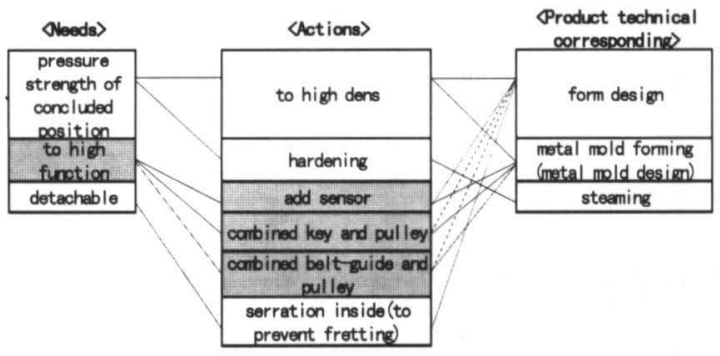

Fig. 5 Needs of drive pulley and method of production technical design.

\section{4 開発事例紹介}

4. 1 ドリブンプーリーの軽量化例について

1) 一例として, 応力解析に基づく徹底的な軽量 化により, $483 \mathrm{~g} \rightarrow 316 \mathrm{~g}$ へ $34.5 \%$ の重量低減を図った例を紹介する。

(Fig. 6 参照)

具体的軽量化内容については,

(1)歯の裏側にカーテン状の肉抜きを施し,歯 底肉厚を $4 \mathrm{~mm}$ から $2 \mathrm{~mm}$ に低減。

(2)フフの厚さを $4.6 \mathrm{~mm}$ から $4.0 \mathrm{~mm}$ に 低隇.

(3)スポークの本数を 6 本から 4 本に低減.

(4)歯幅を $27 \mathrm{~mm}$ から $26 \mathrm{~mm}$ に低減.

また, 上記, 形状を具現化する為の生産技術と しては,粉末を所定の量移動させた後に成形す るいわゆる粉末トランスファー成形の採用と, 各パンチのタワミバランスの適正化を図り,密 度の均一化と成形時のクラック防止を行って いる.

2 ) 次に，最近の事例で，板金製から焼結に置換 した例を紹介する。これは，板金製よりも $18 \%$ 軽量化を達成している.

(Fig. 7 参照)
具体的軽量化内容については,

(1)歯底肉厚を板金の $2.3 \mathrm{~mm}$ から $1.6 \mathrm{~mm}$ に低減。

(2)歯幅を $28.5 \mathrm{~mm}$ から $25.5 \mathrm{~mm}$ に低減.

(3)肉抜き穴の数を 3 ケから 5 ケに, 且つ, 穴 の大きさを拡大.

また, 生産技術対応としては, 前述の粉末トラ ンスファー成形と, 各パンチのタワミバランス の適正化以外にカムシャフト締結部キーの一 体成形を採用しています. 以上の対応により， コスト的にも板金製プーリーを凌ぐ製品とな っている。

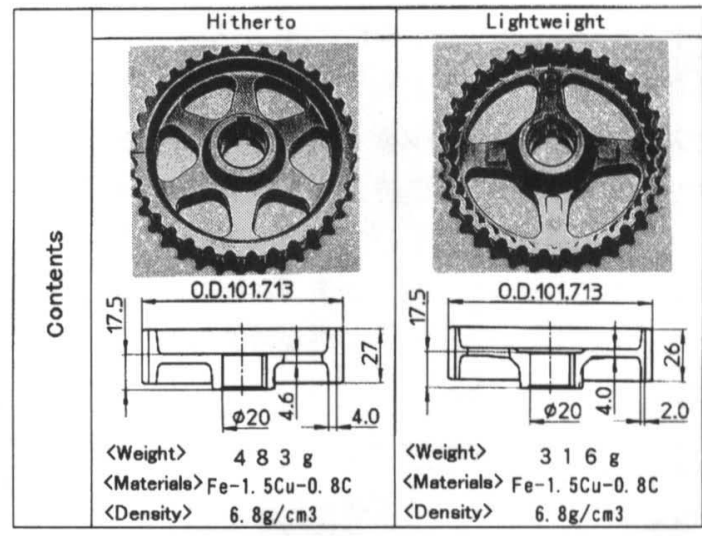

Fig. 6 Light weight driven pulley.

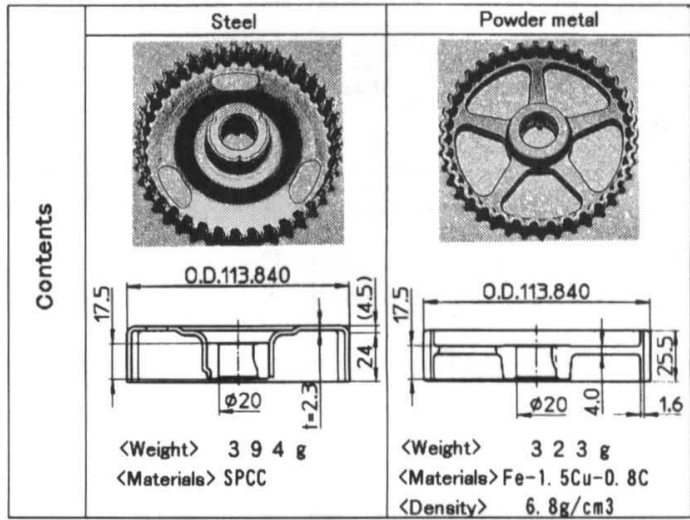

Fig. 7 Light weight driven pulley.

4.2 ドリブンプーリーの高機能化例について センシング機能すなわちカムが付加されているプ ーリーでは, その検知センサーの設置位置の関係によ 
り，リブ端面もしくは南端面にカムが位置している。 カムは何れも機械加エレスの一体成形で具現化して いる.

(Fig. 8 参照)

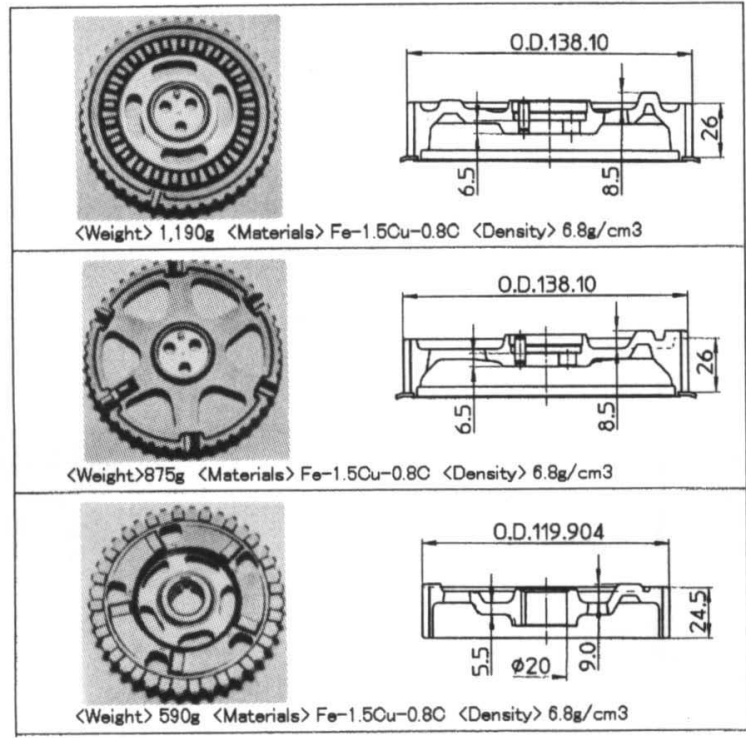

Fig. 8 Extra cam add driven pulley.

生産技術対応としては, 力ムの成形に対し, 力ム形 状，裏側の肉抜き形状をチューニングし，成形時の粉 末の流動を利用し成形しており、これは, 特に, リブ 端面に位置するカムの場合粉末の充填量が不足し, 低 密度による型崩れを防止するためである。

(Fig. 9 参照)

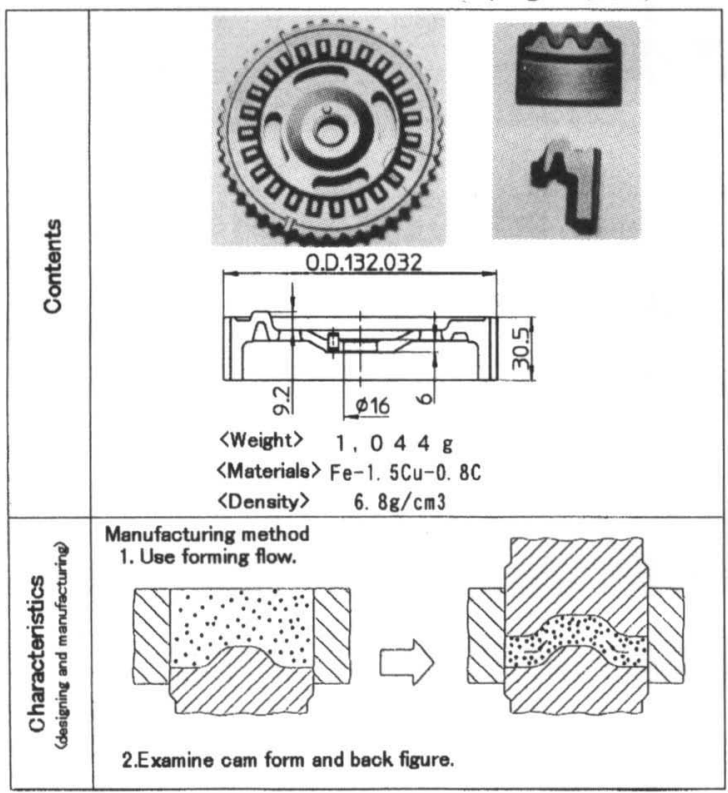

Fig. 9 Method of cam forming.
4.3 ドライブプーリーの高機能化例について

クランクプーリーにも, 96 年モデルから実施され た対米の失火検知対応から, クランクシャフトの角速 度変化をセンシングするためのカムが付加されてい ます。このカムは, 高精度を要求されており, 焼結一 体成形化とする事により，具現化している.

内径キー满に対するカム位置のバラツキ精度は, $3 \sigma$ で 1’2 3”の高精度を達成している.

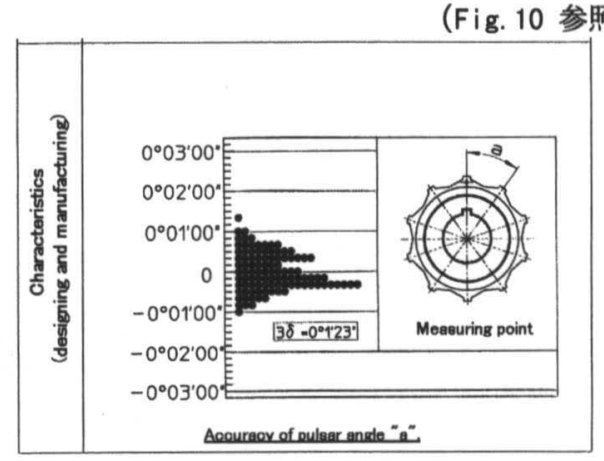

Fig. 10 Cam accuracy data.

生産技術対応としては,センサー部のオーバーハン グ量により成形方案を変えて対応している.オーバー ハング量の少ないものは段付きダイス方式で,多いも のはパンチ分割方式で成形している. また, 締結部の 面圧強度が必要なものについては, スチーム処理を行 っている。

他にも, 凸キー一体成形やフレッテイング防止用の 内径スプライン形状の型出しを行っている.

(Fig. 11 参照)

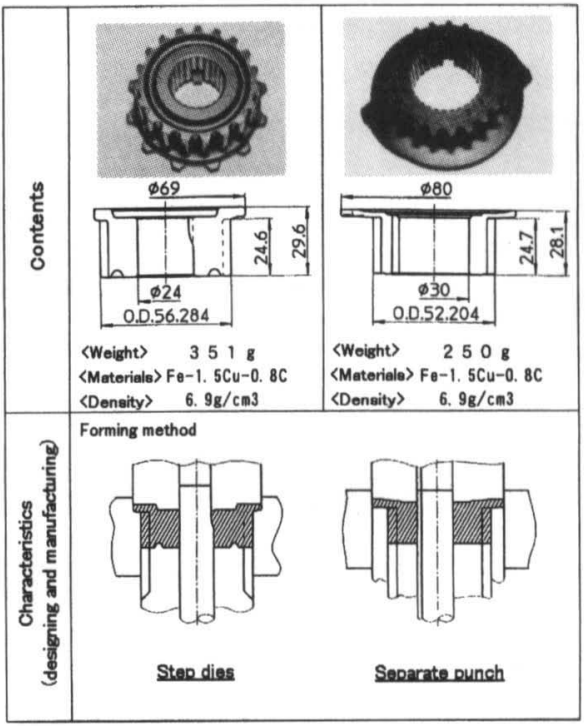

Fig. 11 Method of cam forming. 


\section{5 あとがき}

最近のタイミングベルトプーリは，従来からの機能 に加えて制御用信号および失火検知用センサーとし ての機能が要求されているが,本事例で紹介した様に 成形技術の進歩によりコストパフォーマンスに優れ たプーリを具現化している. 今後, さらにCNCブレ スに代表される様な成形技術の進歩により，粉末治金
製法の特徴である加エレスでの製品化の幅が広が り，より複雑形状部品への適用拡大が期待される.

$$
\text { 文献 }
$$

1）鈴木直弘：日本粉末冶金工業会，第 5 回粉末治金 開発事例発表会講演テキスト,(1991) 